Case Reports in
Gastroenterology
Case Rep Gastroenterol 2020;14:373-376

DOI: $10.1159 / 000508854$

Published online: July 28, 2020
(C) 2020 The Author(s)

Published by S. Karger AG, Basel www.karger.com/crg

This article is licensed under the Creative Commons Attribution-NonCommercial 4.0 International License (CC BY-NC) (http://www.karger.com/Services/OpenAccessLicense). Usage and distribution for commercial purposes requires written permission.

\title{
Systemic Botulism Toxicity Caused by Pyloric Botox Injection to Treat Gastroparesis
}

\author{
Gordon P. Bensen Cristina C. Rutherford Timothy B. Gardner
}

Section of Gastroenterology and Hepatology, Dartmouth-Hitchcock Medical Center, Lebanon, $\mathrm{NH}$, USA

\section{Keywords}

Botulism · Gastroparesis · Toxicity · Complication · Botox

\begin{abstract}
Systemic botulism resulting from therapeutic Botox (OnabotulinumtoxinA) injection has been rarely reported, and never in the context of pylorus injection to treat gastroparesis. We report the case of a 27-year-old female with Emery-Dreifuss muscular dystrophy who developed severe systemic botulism toxicity following the intrapyloric injection of 100 units of Botox to treat gastroparesis. The patient eventually made a full recovery.

(c) 2020 The Author(s)

Published by S. Karger AG, Basel
\end{abstract}

\section{Introduction}

Once used exclusively for cosmetic purposes, Botox (OnabotulinumtoxinA) is now a standard therapy for conditions ranging from cervical dystonia to spasticity, with off-label use in a wide variety of conditions including migraine headaches, anal fissures, and sialorrhea [1]. Increasingly, pyloric injection with Botox has been used to treat recalcitrant gastroparesis [2, 3]. It is typically used in patients who have failed to respond to medical therapy and are still symptomatic. It acts by binding presynaptically to high-affinity recognition sites on the cholinergic nerve terminals and decreasing the release of acetylcholine, causing a neuromuscular blocking effect [4]. 


\section{Case Reports in Gastroenterology}

Case Rep Gastroenterol 2020;14:373-376

DOI: $10.1159 / 000508854$

( 2020 The Author(s). Published by S. Karger AG, Basel www.karger.com/crg

Bensen et al:: Systemic Botulism Toxicity Caused by Pyloric Botox Injection to Treat Gastroparesis

Muscular dystrophy (MD) is a rare genetic disease with approximately 30 different types. The type of MD in our patient, Emery-Dreifuss MD (EDMD), is a heterogenous genetic disorder resulting from mutations that code for proteins providing structure and stability to the nuclear membrane of muscle cells and characterized by progressive muscular weakness, joint contractures, and cardiac disease [5].

Below we detail the first reported case of systemic botulism toxicity caused by pyloric Botox injection to treat gastroparesis in a 27-year-old female with EDMD.

\section{Case Report/Presentation}

A 27-year-old female who suffered from EDMD presented for upper endoscopy with planned Botox injection to treat severely symptomatic gastroparesis. Prior to the endoscopy she had lost $15 \%$ of her total body weight due to severe regurgitation of undigested food and debilitating chronic nausea. She had undergone a 4-h solid-phase gastric emptying scan and CT scan which were consistent with gastroparesis. She used a gastric tube to infuse supplemental elemental feedings and had failed to respond to all prior medical therapy.

The upper endoscopy was performed using monitored sedation with propofol. After ensuring there was no evidence of gastric outlet obstruction, 100 units of Botox (OnabotulinumtoxinA) was injected into the pylorus (25 units into each quadrant). The injections were unremarkable, with no evidence of intra-arterial injection, and she was discharged from the recovery area $1 \mathrm{~h}$ after the procedure feeling well. Two hours post-procedure, she experienced weakness in her bilateral lower extremities, which progressed rapidly to her upper extremities. Within $3 \mathrm{~h}$ post-procedure, she became unable to walk and was brought to the emergency department by private vehicle $3.5 \mathrm{~h}$ after the Botox injection.

Upon arrival, she was evaluated by the neurology service who noted diffuse muscle weakness $(1 / 5)$ in all muscles - with only the ability to slightly flex her neck. Her lower extremities were weaker than her upper extremities. She complained of inspiratory weakness but did not require endotracheal intubation.

Both systemic botulism and acute inflammatory demyelinating polyneuropathy were considered as potential causes for her symptoms, and a lumbar puncture was performed. Her cerebrospinal fluid was normal without increased protein and given the temporal relationship of her symptoms to the injection, systemic botulism toxicity was felt to be more likely. The Centers for Disease Control and Prevention (CDC) was contacted and recommended administration of the botulism anti-toxin. The anti-toxin was then urgently transported by commercial airline and courier from Atlanta, GA (CDC), to Lebanon, NH (Dartmouth-Hitchcock Medical Center), and given approximately $8 \mathrm{~h}$ following the endoscopy.

The patient was admitted to the ICU and treated in the ICU and step-down units with aggressive physical and respiratory therapy. She did not require mechanical ventilation. While in the hospital she underwent an EMG, which demonstrated no evidence of demyelination or peripheral neuropathy, but did show myopathic potentials in her right leg. She slowly improved in all her muscle strength and was discharged to a rehabilitation center after a 12-day hospitalization. Six months following the endoscopy, she had recovered all muscle function back to her baseline. 


\section{Case Reports in Gastroenterology}

\begin{tabular}{l|l}
\hline Case Rep Gastroenterol 2020;14:373-376 \\
\hline DOI: 10.1159/000508854 & $\begin{array}{l}\text { ○ 2020 The Author(s). Published by S. Karger AG, Basel } \\
\text { www.karger.com/crg }\end{array}$ \\
\hline
\end{tabular}

Bensen et al.: Systemic Botulism Toxicity Caused by Pyloric Botox Injection to Treat Gastroparesis

\section{Discussion/Conclusion}

This represents the first documented case of systemic botulism toxicity caused by Botox injection into the pylorus. It also represents the first reported case of systemic botulism in a patient with EDMD. The two most common forms of MD, Duchenne and Becher, result from a mutation in the gene that codes for dystrophin - a protein that strengthens muscle fibers and protects them from injury. The type of MD in our patient, EDMD, is a heterogeneous genetic disorder resulting from mutations that code for proteins providing structure and stability to the nuclear membrane of muscle cells. There are currently 6 known gene mutations that lead to EDMD, 5 of which involve mutations in proteins that are a part of the linkage system between the nucleoskeleton and the cytoskeleton. Clinically, EDMD demonstrates slowly progressive humeroperoneal muscle weakness/wasting and cardiac disease with eventual conduction defects, arrhythmias, and cardiomyopathy. Patients with EDMD are at risk of sudden cardiac death from heart block and progressive heart failure and most require a combination pacemaker/defibrillator.

Botox has been frequently reported as a safe intervention in MD patients to treat spastic contractures, raising the question as to why our patient with EDMD developed systemic botulism toxicity. We hypothesize that our patient's underlying EDMD resulted in a profound baseline reduction of her muscle cell function to respond normally to acetylcholine at the neuromuscular junction. When the Botox was introduced, it likely further reduced the already limited capacity of her muscles to respond to acetylcholine stimulation, leading to her clinical symptoms.

To our knowledge, this is the first reported case of systemic botulism resulting from Botox injection into the pylorus to treat gastroparesis, as well as the first reported case in a patient with EDMD. With the increasing frequency of Botox use in clinical practice, endoscopists should be aware of this potential complication, especially in patients with underlying neuromuscular disorders.

\section{Statement of Ethics}

The subject gave her written informed consent to publish her case.

\section{Conflict of Interest Statement}

None of the authors have any conflicts of interest.

\section{Funding Sources}

There was no funding source for this study. 
Case Reports in Gastroenterology

\begin{tabular}{l|l}
\hline Case Rep Gastroenterol 2020;14:373-376 \\
\hline DOI: 10.1159/000508854 & $\begin{array}{l}\text { @ 2020 The Author(s). Published by S. Karger AG, Basel } \\
\text { www.karger.com/crg }\end{array}$ \\
\hline
\end{tabular}

Bensen et al:: Systemic Botulism Toxicity Caused by Pyloric Botox Injection to Treat Gastroparesis

\section{Author Contributions}

Mr. Bensen, Dr. Rutherford, and Dr. Gardner all participated in the planning and writing of the manuscript. Each approved the final draft of the manuscript.

All authors contributed equally to the planning, writing, and review of the manuscript.

\section{References}

1 Brin MF. Basic and clinical aspects of BOTOX. Toxicon. 2009 Oct;54(5):676-82.

2 Pasricha TS, Pasricha PJ. Botulinum toxin injection for treatment of gastroparesis. Gastrointest Endosc Clin N Am. 2019 Jan;29(1):97-106.

3 Thomas A, de Souza Ribeiro B, Malespin M, de Melo SW Jr. Botulinum toxin as a treatment for refractory gastroparesis: a literature review. Curr Treat Options Gastroenterol. 2018 Dec;16(4):479-88.

4 Ukleja A, Tandon K, Shah K, Alvarez A. Endoscopic botox injections in therapy of refractory gastroparesis. World J Gastrointest Endosc. 2015 Jul;7(8):790-8.

5 Bonne G, Quijano-Roy S. Emery-Dreifuss muscular dystrophy, laminopathies, and other nuclear envelopathies. Handb Clin Neurol. 2013;113:1367-76. 